\title{
ПЕРЕХРЕСНІ СТЕЖКИ МИКОЛИ ЛУКАША І ПАНТЕЛЕЙМОНА КУЛШЫА
}

\author{
ВАЛЕНТИНА САВЧИН \\ Львівський національний університет імені Івана Франка, Львів — Україна \\ vrsavchyn@rambler.ru \\ PRZECINAJĄCE SIĘ ŚCIEŻKI \\ MYKOŁY ŁUKASZA I PANTELEJMONA KULISZA
}

WALENTYNA SAWCZYN

Lwowski Uniwersytet Narodowy imienia Iwana Franki, Lwów — Ukraina

STRESZCZENIE. Artykuł omawia działalność Mykoły Łukasza przez pryzmat ciągłości tradycji artystycznych oraz wielorakich aluzji intertekstualnych w jego tłumaczeniach. Autorka skupia uwagę na unikatowej właściwości poetyki M. Łukasza - aktywnym wykorzystaniu leksyki, idiomów oraz języka metaforycznego, pochodzących z folkloru oraz ukraińskiej tradycji literackiej, zwłaszcza z twórczości P. Kulisza. Metoda przekładu M. Łukasza jest analizowana w kontekście funkcji kształtowania narodu, którą pełni ukraiński przekład artystyczny w zestawieniu z kulturologiczną misją P. Kulisza.

\section{THE CROSSROADS OF MYKOLA LUKASH AND PANTELEYMON KULISH \\ VALENTYNA SAVCHYN \\ Ivan Franko National University of Lviv, Lviv — Ukraine}

\begin{abstract}
The article discusses the activities of M. Lukash through the prism of continuity of artistic traditions and broad intertextual links of his translations. The primary focus of this research is on the unique feature of M. Lukash - the intensive use of lexical, idiomatic and figurative resources accumulated in Ukrainian folklore and literary traditions with particular reference to works of P. Kulish. The translation methods employed by M. Lukash are viewed in the nation shaping dimension of Ukrainian literary translation and compared explicitly with the cultural activities of P. Kulish.
\end{abstract}

$\mathrm{B}$ історії кожного народу переклад посідає особливе місце. Він завжди $\epsilon$ засобом опосередкованого спілкування, взаємопроникнення літератур, могутнім джерелом збагачення національної культури. Для українського народу, з огляду на здеформований розвиток оригінальної літератури, численні утиски у функціонуванні українського слова, значення художнього перекладу було значно ширшим. Він був важливим компенсаційним засобом, чинником розвитку і збагачення української мови та літератури, національно-культурного самоствердження. Звідси - надзвичайно висока місія перекладача не лише як посередника в зближенні народів і культур, а і як митця, який підносить національну культуру до належного рівня й засвідчує силу й досконалість рідного слова.

Цю розвідку присвячено творчості двох визначних постатей історії українського художнього перекладу - Миколі Лукашу й Пантелеймону Кулішу, мит- 
цям, які належали до різних епох та яких об’єднала культурологічна місія - бачення майбутнього України та її мови.

Географічно П. Куліша і М. Лукаша можна вважати земляками - уродженцями Сумщини, у часовому ж вимірі між ними - ціле століття. П. Куліш народився 1819 р., М. Лукаш — рівно через сто років - у 1919 р. Обидва стали знаковими постатями для своїх епох. Обидва гостро реагували на історичні та суспільно-політичні виклики своєї доби, обидва були свідомі своєї місії.

М. Лукашеві випало творити в непросту й суперечливу добу, коли - попри теорію про злиття націй і мов, ідеологічний тиск, цензурні обмеження та вихолощення української мови - спостерігалося нестримне зростання творчих сил, піднесення та усвідомлення значущості української перекладацької творчості. Художній переклад перебирав на себе певною мірою функції оригінальної літератури, так забезпечуючи цілісність літературної полісистеми. Для митців цієї доби художній переклад став важливим, а часто єдиним засобом самовираження, що дозволяв цілеспрямовано добирати твори для перекладу з огляду на (а) можливість залучення різноманітних мовно-стилістичних ресурсів, на які існували обмеження в оригінальній літературі, (б) їхнє культурне чи ідеологічне значення. Важливість останнього можна проілюструвати думкою М. Коцюбинської про те, що „в 60-ті підтекст певною мірою замінював для читача естетичні цінності"1. Тож за рядками перекладу могли виразно вчуватися національно-патріотичні, волелюбні, антирежимні мотиви.

Усупереч несприятливим культурно-історичним обставинам виникло подвижництво - феномен, завдяки якому українська культура зуміла не просто вижити в жорстких, неприродних умовах розвитку, а самоствердитися й розвиватися. М. Лукаш, як і більшість перекладачів, не брав безпосередньої участі в русі національного опору 60-х, не позиціонував себе відкрито як дисидента. Але за духом творчості, літературними смаками простежуються ідеї та погляди шістдесятників. Як висловився Л. Танюк, „,[Григорій] Кочур і Микола Лукап були ті перпі ппістдесятницькі євроінтегратори, які відкривали нам пाирокий світ європейської і ширше - світової культури"2. Тож перекладацькокультурницька праця М. Лукаша в контексті національної ідеї співмірна 3 подвижництвом шістдесятників i, як виявилося невдовзі, була засуджена режимом.

Переклади М. Лукаша, окрім згаданого вже глибокого підтексту, мали й іншу особливість, що виразно дисонувала з пропагованою тоді ідеєю “української радянської культури" та обмеженням сфери функціонування української мови до "хатнього вжитку". Демонструючи своїми перекладами абсолютну повноцінність української мови та стверджуючи високий, якісно новий рівень української культури, М. Лукаш перекреслював усі постулати тоталітарної ідеології. Для нього пріоритетом був цільовий текст, що відповідав би потребам цільової літератури та культури й демонстрував би багаті виражальні можливості цільової мови. Такий підхід перекладача цо вибору як самих творів для перекладу, так і конкретних перекладацьких прийомів, дозволив дослідникам його творчості говорити про глибоку й усвідомлену культурологічну місію М. Лукаша. На думку М. Новикової, М. Москаленка, Л. Коломієць, основною ідеєю перекладацької творчості М. Лукаша було щось значно більше, ніж

${ }^{1}$ M. Х. Коцюбин ська, Мої обрії, в 2 томах, Київ 2004, т. 2, с. 351.

2 Л. С. Танюк, Уроки Григорія Порфировича, [в:] Григорій Кочур і украйнський переклад, Матсріали міжнар. наук.-практ. конф., Київ-Ірпінь 27-29 жовт. 2003 р., рсдкол. О. Ч с р с д н и ч с н ко (голова) та ін., Київ-Ірпінь 2004, с. 67. 
намагання вплинути своїми перекладами на стан та перспективи розвитку національної культури, — йому йшлося про пересотворення / створення альтернативної історії української культури та літератури засобами художнього перекладу ${ }^{3}$.

У такій площині очевидною стає паралель між культуротворчою ідеєю М. Лукаша та культурництвом П. Куліша. Спостереження про вплив П. Куліша на перекладацьку творчість М. Лукаша висловлювали М. Москаленко ${ }^{4}$, М. Стрі$\mathrm{xa}^{5}$, О. Лучук 6 , М. Самійленко ${ }^{7}$ та інші дослідники, убачаючи в цьому неперервність традицій українського художнього перекладу. 3 іншого боку, певні аналогії у творчості обох перекладачів отримали виразно негативну оцінку, як, напр., закиди Л. Первомайського щодо мовної “екстравагантності”, якої М. Лукаш навчився у П. Куліша ${ }^{8}$.

Попри неоднозначність оцінок, незмінним залишається той факт, що П. Куліш був учителем М. Лукаша (про що останній згадував неодноразово) й орієнтиром у його перекладацькій діяльності. М. Лукаш високо цінував оригінальну та перекладну творчість П. Куліша, його мовне новаторство, багато чого в нього запозичив. Отже, мовно-стилістичні пошуки М. Лукаша, його новації, прагнення до експерименту зі словом, широке використання народнопоетичних ресурсів мови сягають своїм корінням Кулішевої творчості й засвідчують неперервний зв'язок у розвитку українського перекладу.

У такому контексті доречно, мабуть, говорити про окрему течію в нашому перекладацтві, яку найвиразніше репрезентували П. Куліш та М. Лукаш і яка максимально опиралася на фольклор та традиції бароко. В основі цієї течії - високий рівень мовного експериментаторства, що проявляється, за характеристикою М. Стріхи, у великих зрушеннях у лексичній тканині перекладу, часо-просторових зміщеннях, орієнтації на свідому архаїзацію, українізацію реалій, активному залученні діалектного й фольклорного матеріалу9. Таку традицію перекладу виділяють на противагу т. зв. “класичній” традиції, пцо білыпе орієнтована на вироблені літературні норми і вирізняється своїм академізмом. До першої (“фольклорноі” / “барокової”) традиції, окрім П. Куліша та М. Лукаша, умовно зараховують Є. Гребінку, П. Грабовського, раннього П. Тичину, В. Самійленка, І. Костецького, В. Барку. До другої належать М. Старицький, I. Франко, М. Зеров, М. Рильський, Д. Паламарчук, Г. Кочур та ін. Зачинателем “бароковоі”” течії вважають П. Куліша, а їі найяскравішим представником - М. Лукаша.

Переклади П. Куліша вирізняються лексичною різноманітністю й мовною строкатістю, у них давні архаїчні пласти лексики та фразеології поєднані з роз-

${ }^{3}$ М. О. Нов иков а, Мiфи тамісія, Київ 2005, с. 44; М.Н. Москале н ко, Високий иилях Миколи Лукаша, [в:] М. О. Лукаш, Від Боккаччо до Аполлінера, Переклади, Київ 1990, с. 7; Л. В. Коломієць, Конщептуально-методологічні засади сучасного украйнського поетичного перекладу (на матеріалі перекладів з англійської, ірландської та американської поезіі), Київ 2004, c. 337.

${ }^{4}$ М. Н. Москка ле нко, Високий илях Миколи Лукамиа, ..., с. 6-7.

${ }^{5}$ М. Ст ріха, Украйнський художній переклад: між літературою і націстворениям, Кийв 2006, c. 87.

${ }^{6}$ О. М. Лучук, Діалогічиа природа літератури: Перекладозиавчі та літературозиавиі париси, Львів 2004, с. 27-35.

${ }^{7}$ М. О. С амі йл енко, Собори високих дуии, [в:] „Зерна" 1998, ч. 4-5, с. 159-160.

8 Л. С. Пер в омайс ьк и й, ,Фауст” Гете в перекладі М. Лукаша, [в:] Й ог о ж, Творчий будень: 3 щоденника поета, Київ 1967, с. 323-324.

${ }^{9}$ М. С т рі ха, Украйнський художсній переклад: між літературою інацістворенням, ..., с. 91. 
мовними й народнопісенними елементами. Численні церковнослов'янізми й іншомовні запозичення обтяжували стиль, проте, на думку перекладача, свідчили про розвиток української мови і їі культурний потенціал: „наша мова із простонародньої ступила вже вгору і забирає в себе слова і форми із Святого Письма"10. П. Куліш намагається продемонструвати міць і потугу української мови, ії придатність до функціонування в значно ширших жанрово-стилістичних контекстах, залучаючи до вжитку ресурси і староукраїнської книжної мови, і живої народнорозмовної стихії. Саме такий синтез, що ліг в основу Кулішевої теорії “староруського відродження” української мови, мав би, на його думку, створити високий стиль та забезпечити українській мові статус літературної. Кулішева теорія виникла як реакція на обмежене функціонування української мови, що зводилася до мови побутового спілкування, поширені тоді твердження про непотрібність українських перекладів та пропаговану теорію “общерусского языка".

Куліш вірив у можливості українського слова, неодноразово наголошував, що українська літературна мова ще дуже молода, а тому, щоб стати повноцінною мовою української літератури, повинна черпати „і від народу, що понашому розмовляє, і $з$ науки, котра нашу старовину освічує"11. Реформаторські погляди П. Куліша на розвиток української мови супроводжувалися його намаганнями здійснити на практиці, за визначенням Юрія Шевельова, „радикальну перебудову літературної мови, що межувала з ії творенням"12. На мовотворчій діяльності П. Куліша наголошує і В. Сімович, зазначаючи, що мова його творів - це „мова, яку Куліш вироблював як неперевершений досі ніким знавець iï законів, iї духа, iї скла́дні, знавець тих шляхів, якими вона має йти у свойому розвитку [...]. Куліш творив свою мову — нашу літературну мову — 3 поглядом на майбутнє, з погляду на шлях їі майбутнього розвитку"13.

Кулішеві йшлося не стільки про розширення словника української літературної мови, що було логічним наслідком його теорії “староруського відродження" мови, скільки про значно далекосяжніпу мету — культурний поступ і духовне зростання української нації. „Спасеніє нашого краю - в нашому слові”, - писав П. Куліш у листі до Г. Галагана від 3 березня 1857 p. ${ }^{14}$ Ця ж думка резонує згодом у його поетичній збірці „Дзвін” (1893 р.), зокрема у поезії До Mарусі В[овківни], заклику, що вже став крилатим: Отечество ж собі трунтуймо в ріднім слові: / Воно, одно воно від пагуби втече, / Піддержить начію на предківській основі...15.

Са́ме культурне і національне відродження України через відродження мови споріднює П. Куліша і М. Лукаша. Вони однаково глибоко відчували потребу престижу українського слова і зверталися до перекладу як до засобу збагачення рідної мови та літератури через освоєння інтелектуальних і духовних багатств людства. Для П. Куліша переспіви і переклади творів чужих літератур були інструментом “європеїзації” української літератури, виведення ії на сві-

${ }^{10}$ Вибрані листи Пантелеймона Куліша украйнською мовою писані, за ред. Ю. Луць кого, Нью-Йорк, Торонто 1984, с. 114 (лист до О. Милорадович від 03.05.1857р.).

${ }^{11}$ Там само, с. 122 (лист до О. Барвінського від 03.03.1876 р.).

${ }^{12}$ Ю. Ш Е вел ь о в, Кулішеві листи і Куліш у листах, [в:] Й ого ж, Вибр. праиі, у 2 кш., Кийв 2008, кн. 2: Літературознавство, с. 188.

${ }_{13}$ В. С ім о в и ч, Куліш: 3 нагоди сорокаліття смерти, [в:] Й ого ж, Праиі, у 2 томах, Чернівці 2005, т. 2: Літературознавство. Культура, с. 404.

${ }^{14}$ Вибрані листи ..., с. 106.

${ }^{15}$ П. О. Куліш, Твори, у 2 томах, 2-ге вид., Київ 1998, т. 1, с. 494. 
тові обшири. Для М. Лукаша художній переклад став важливим чинником національного відродження, каталізатором мовного, літературного та культурного розвитку.

П. Куліш творив українську мову, щоб розширити межі українського слова, перекладав, „шоб виробить форми змужичалої нашої речі на послугу мислі всечоловічій" "16. М. Лукаш відроджував рідну мову, яка відчула на собі тиск радянської асиміляційної політики, відновлював її здеформовану структуру. Для цього перекладач звертався до найрізноманітніших історичних, літописних, фольклорних, літературних джерел як до скарбівні питомих лексичних та синтаксичних ресурсів. „Нам треба гребти лопатою мовні скарби, надбані нашими попередниками, пускати їх в обіг, переводити з пасиву в актив", - наголошував М. Лукаш в інтерв'ю з А. Перепадею ${ }^{17}$.

П. Куліш приваблював М. Лукаша чи не найбільше. Приваблював експериментаторством, лексичними знахідками, бароковою строкатістю. „Це такий знавець мови, як рідко хто був", — говорив М. Лукаш, указуючи на необхідність видання його перекладів ${ }^{18}$. Саме тому і звертався до творчості П. Куліша у своїх стилістичних та образних пошуках. Про це він згадує в листі до Г. Кочура від 5 березня 1966 р.: „Дуже мені допомагає гарячий Панько - ніхто все-таки краще за нього нашої мови не знав! Коли перекладав вставну новелу Повість невольника, я взяв із Кулішевого Байди не тільки деякі турецькі реалії (капуданбаша зам. командуючий флотом, замковий ага - комендант фортеці, райз каnimaн (в ісп. транскрипції arráez) тощо), а й цілі отакі вирази — «звелів їм братись поуз саму скелю», «від берега щодальше одвертаймо», «Геруйте деменами до лиману» тощо”"19. А далі - висновок: „От як обкрадає класик класиків! ”20. Нижче наведемо контексти, у яких М. Лукаш ужив деякі зі згаданих у листі образні запозичення з П. Куліша.

\begin{tabular}{|c|c|}
\hline Пантелеймон Куліш & Микола Лукаш \\
\hline $\begin{array}{l}\text { Б’ємось ми велетнями за галеру, } \\
\text { Що в капудан-баші взяли на морі } \\
\text { (Куліш, Байда, князь Вишневецький) }\end{array}$ & $\begin{array}{l}\text {...і високо пішов - став алжир- } \\
\text { ським деєм, а згодом капудан- } \\
\text { башею, себто третім найвищим } \\
\text { достойником у царстві } \\
\text { (Сервантес, Дон Kixom) }\end{array}$ \\
\hline $\begin{array}{l}\text { — Агов, рушаймо!.. } \\
\text { Від берега шуодальше одвертаймо, } \\
\text { Безкраїм морем певну путь верстаймо! } \\
\text { (Куліш, Байда, киязь Вишневецький) }\end{array}$ & $\begin{array}{l}\text {...проте старались ми од берега } \\
\text { щуодальше одвернути і вийти в чи- } \\
\text { сте море } \\
\text { (Сервантес, Дон Kixom) }\end{array}$ \\
\hline $\begin{array}{l}\text { Додому, панове браттє! Керуймо } \\
\text { деменами до лиману! } \\
\quad \text { (Куліш, Байда, князь Вишневецький) }\end{array}$ & $\begin{array}{c}\text { Вони поплили в чисте море, } \\
\text { керуючи деменом до протоки... } \\
\text { (Сервантес, Дон Kixom) }\end{array}$ \\
\hline
\end{tabular}

${ }^{16}$ Вибрані листи ..., с. 105 (лист до Г. Галагана від 30.03.1857 р.).

${ }_{17}$ Десята муза, ІІттерв' го вів А. О.Пер еп а дя, [в:] „Україга: Наука і культура. 1966”, Київ 1966, c. 412.

${ }^{18}$ Там само.

${ }^{19}$ Примітка. Листи М. Лукаша до Г. Кочура зберігаються у фондах Літературного музею Григорія Кочура в Ірпені.

${ }^{20}$ Там само. 


\begin{tabular}{|c|c|}
\hline $\begin{array}{l}\text { Звслів їм братись поуз саму скелю? } \\
\text { (Куліш, Байда, киязь Вишневецький) }\end{array}$ & $\begin{array}{l}\text {...море зашпувало, і годі нам } \\
\text { було плисти, куди намірились, } \\
\text { мусили повз самий берег в Оран- } \\
\text { ському напрямі братись } \\
\text { (Сервантес, Дон Kixom) }\end{array}$ \\
\hline $\begin{array}{r}\text { (Куліш, Байда, князь } \\
\text { Вишневецький) }\end{array}$ & $\begin{array}{l}\text {...живе там багатий і знакомий } \\
\text { мавр на ймення Хаджі-Мурат, } \\
\text { колишній замковий ага в укріпле- } \\
\text { ному місті Пата, а то в них вважа- } \\
\text { ється дуже високою посадою } \\
\text { (Сервантес, Дон Kixom) }\end{array}$ \\
\hline
\end{tabular}

Таке залучення мовних надбань своїх попередників $\epsilon$ унікальною рисою перекладацького методу М. Лукаша та важливим чинником майстерності його перекладів. Архівні матеріали перекладача проливають світло на масштаби Лукашевого опрацювання українських літературних джерел і зокрема доробку П. Куліша. Серед них виділимо такі: 1) лексикографічна картотека М. Лукаша; 2) книжкові та журнальні видання з Лукашевими підкресленнями та нотатками; 3) зошити, записники з виписками з Кулішевих перекладних та оригінальних творів.

Із цих та інших архівних матеріалів видно, що Лукаш звертав увагу й на лексико-фразеологічні особливості мови П. Куліша (використання застарілої лексики, діалектизмів, неологізмів, плеоназмів, тавтологічних зворотів, фразелогізмів) і на граматичні риси - уживання числівників, модальних слів, дієслівних присудків, збіг іменників, граматичної категорії дієслова “стан” та ін. Особливо ретельно М. Лукаш розписав Кулішеву Чориу раду, його переклади Шекспірових п'єс та Дон Жуана Байрона (наведемо для ілюстрації деякі одиниці Кулішевого слововжитку, що привернули увагу М. Лукаша: недовірство, несмаковитий, здуріння, звітрілі слова, збайстрючене слово, невитворне слово, лежнювати, завдовіти, мишоловщция (сова), ненавидець, ненавидник, злорікий світ, кривосудний, запеклосердий, мідянопикий).

Цікаво те, що більшість Кулішевих знахідок М. Лукаш використав згодом у перекладах. Про деякі вже згадувалося вище, інші ж проілюструємо порівняльними контекстами:

\begin{tabular}{|c|c|}
\hline Пантелеймон Куліш & Микола Лукаш \\
\hline $\begin{array}{l}\text { — Не діжде свиноӥзд над нами } \\
\text { гетьмановати! } \\
\text { (Куліш, Чорна рада) }\end{array}$ & $\begin{array}{r}\text {...чи були в яких-небудь ман- } \\
\text { дрованих рицарів джури-ослойзди } \\
\text { (Сервантес, Дон Kixom) }\end{array}$ \\
\hline $\begin{array}{c}\text { А шкода пускати на світ такого } \\
\text { гріховода: і так уже чор'знає на що } \\
\text { переводиться славне Запорожжє } \\
\text { (Куліш, Чорна рада) }\end{array}$ & $\begin{array}{l}\text { Той гріховода, } \\
\text { Старий, плюгавий } \\
\text { Та ще й кульгавий, } \\
\text { Летить за нами } \\
\text { Немов без тями } \\
(\text { (Іете, Фaycm) }\end{array}$ \\
\hline
\end{tabular}




\begin{tabular}{|c|c|}
\hline $\begin{array}{l}\text { Здоров був, братику! Бач, як гарно } \\
\text { в нас трактують гостей? } \\
\text { (Куліш, Чорна рада) }\end{array}$ & $\begin{array}{l}\text {...він посадив своїх гостей } \\
\text { до столу й почав трактувати їх } \\
\text { найвиборнішими наїдками } \\
\text { (Боккаччо, Декамерон) }\end{array}$ \\
\hline $\begin{array}{l}\text { І ножака блиснув } \\
\text { Проти зір, і очі, } \\
\text { Від ножа лютіші, світять } \\
\text { В сутемряві ночі } \\
\quad \text { (Куліш, Маруся Богуславка) }\end{array}$ & $\begin{array}{l}\text { Уже світанок, прогнавши } \\
\text { сяєвом своїм сутемряву ночи, } \\
\text { перемінив синяву восьмого неба } \\
\text { на ніжний блакит } \\
\text { (Боккаччо, Декамерон) }\end{array}$ \\
\hline $\begin{array}{l}\text { Всі одвернулися од правди, } \\
\text { всі зледащіли, розопсіли... } \\
\text { (Куліш, Псальма XIV) }\end{array}$ & $\begin{array}{r}\text { Од сього вони зледащуіли та } \\
\text { розопсіли, як і городяне... } \\
\text { (Боккаччо, Декамерон) }\end{array}$ \\
\hline $\begin{array}{l}\text { Булю гучно, булю бучно, } \\
\text { Та встав брат на брата } \\
\text { (Куліш, Настуся) }\end{array}$ & $\begin{array}{r}\text { Так вони і вчинили: без иро- } \\
\text { водів, не гучно і не бучно подалися } \\
\text { з Флоренції прямісінько до Англії } \\
\text { (Боккаччо, Декамерон) }\end{array}$ \\
\hline $\begin{array}{l}\text { Ми ж, стратенці бесурменські, } \\
\text { Обреклись оброком } \\
\text { Нищити краї турецькі } \\
\quad \text { (Куліш, Маруся Богуславка) }\end{array}$ & $\begin{array}{l}\text { Якби ти хотів, ти міг би блуду- } \\
\text { вати з більшою свободою, ніж ми } \\
\text { і тії, що оброком обреклися } \\
\text { (Боккаччо, Декамерон) }\end{array}$ \\
\hline $\begin{array}{l}\text { Ахил звелів міні сказати: шкода, } \\
\text { Коли що поважнійше, ніж забава } \\
\text { Подвигнула твое царське величчє } \\
\text { Из благородним почтом завитати } \\
\text { До нёго. } \\
\text { (куліш, Троіл ти крессиоа (переклад)) }\end{array}$ & $\begin{array}{l}\text { Ахілл мені велів сказати: жаль, } \\
\text { Коли щось інше, а не власна втіха, } \\
\text { Подвигнула твою високу гідність } \\
\text { Прийти сюди із почтом благородним. } \\
\text { (Шекспір, Троїл і крессіда) }\end{array}$ \\
\hline $\begin{array}{c}\text { Рогач шчепивсь из рогоробом. } \\
\text { (Куліш, Троіл та Крессида (переклад)) }\end{array}$ & $\begin{array}{l}\text { О, зчепились уже, рогонос із рого- } \\
\text { робом. } \\
\text { (Іекспір, Троїл і Крессіда) }\end{array}$ \\
\hline
\end{tabular}

ІІерший приклад демонструє творче використання Кулішевого оказіоналізму. Перекладаючи Дон Kixoma, М. Лукаш натрапив на новотвір Сервантеса asnalmente (той, що їздить на віслюці). Пригадавши, що в Чорній радi козаки дражнили Брюховецького свиноӥздо, перекладач утворив за аналогією ослоӥзд. М. Лукаш радів із цієї знахідки, підкреслюючи ії лаконічність порівняно з російським перекладом Н. Любимова (“оруженосец, который прибегал к ослиному способу передвижения").

М. Лукаш активізує лексико-фразеологічні надбання П. Куліша і з його оригінальних, і з перекладних творів. Останні з наведених прикладів цікаві ще й тим, що демонструють паралелі між слововжитком М. Лукаша і П. Куліша на матеріалі перекладів одного й того ж оригіналу - драми Шекспіра Тройл i Kpeccida. Це один з небагатьох творів, над яким перетнулися шляхи перекладачів. Окрім нього, перекладачів приваблювала творчість Байрона, німецьких поетів-романтиків. 
Зіставний аналіз цих перекладів може допомогти краще відслідкувати вплив П. Куліша на перекладацьку творчість М. Лукаша. Та однозначним залишається той факт, що попри схожі поетичні та перекладацькі уподобання, М. Лукаша і П. Куліша поєднує дещо значно глибше - національно-культурний контекст доби, на яку припала творчість кожного зокрема, глибоке усвідомлення потреб української культури та свого покликання як митця, що може задовольнити ці потреби. 